\title{
TEACHING ENGLISH VOCABULARY ONLINE: IS THE SCREEN A BARRIER?
}

\author{
Oksana Zabolotna ${ }^{1}$, Liudmyla Zagoruiko ${ }^{2}$, Ielyzaveta Panchenko ${ }^{3}$, Yevhen Plotnikov ${ }^{4}$ \\ ${ }^{1,3}$ Pavlo Tychyna Uman State Pedagogical University, Uman, Ukraine \\ ${ }^{2}$ National Aviation University, Kyiv, Ukraine \\ ${ }^{4}$ Nizhyn Mykola Gogol State University, Nizhyn, Ukraine
}

o.zabolotna@udpu.edu.ua

\begin{abstract}
This paper presents mixed-method research on teaching vocabulary online using a combination of quantitative (bibliometric approach) and qualitative (expert evaluation based on Delphi technique) methods to answer three research questions: Which tools in teaching language with technology have been described in research publications? Which tools are frequently addressed in EFL Methodology course in Ukrainian universities for teaching vocabulary online? Which tools and methods require more information for teaching vocabulary online? To answer the first research question, the authors have used a bibliometric approach to analyse the topicrelated articles in the eight most relevant journals from the Scopus Database between 2011 and 2020. The authors have encountered few literature review articles tracking the developments in this research area and no articles using bibliometric methods or science maps. After finalising and structuring the bibliometric analysis data, the authors have used the Delphi method with the British Council experts who were involved in the New Generation School Teacher Project. The experts who are EFL Methodology teachers at 7 Ukrainian Universities have shared their experience in using the tools identified by the bibliometric analysis and listed the usability precedency and hurdles with their recommendations. The experts assisted in answering the research questions about the tools addressed in the EFL methodology course and those that require some consideration. As a result, the findings are collated and shared with EFL teachers, and they can gain valuable insights into the current state of the research and practice in this area. In the discussion part, the authors familiarise EFL teachers with the newest resources that provide information about the understudied areas.
\end{abstract}

Keywords: teaching vocabulary online; bibliometric approach; computer-assisted language learning, EFL Methodology course.

\section{Introduction}

The challenges in education caused by the COVID-19 pandemic have led to the shift to online learning as a predominant instruction mode. However, face-to-face communication has always been a cornerstone of teaching and learning English as a Foreign Language as it gave the chance to develop Grammar and Vocabulary, putting them in a communicative context. As a result, the EFL Methodology course has relied on communicative, task-based and constructivist approaches. So today, novice and experienced teachers are equal in their need for seeking technology-assisted tools for teaching grammar and vocabulary online. This paper presents mixed-method research on teaching vocabulary online using a combination of quantitative (bibliometric approach) and qualitative (expert evaluation based on Delphi technique) methods to answer three research questions: Which tools in teaching language with technology have been described in research publications? Which tools are frequently addressed in EFL Methodology course in Ukrainian universities for teaching vocabulary online? Which tools and methods require more information for teaching vocabulary online? The aim of the article is to collate and share the findings with EFL teachers so that they gain valuable insights into the current state of the research and practice in this area. In the discussion part, the authors familiarise EFL teachers with the newest resources that provide them with information about the areas that the experts identified as understudied.

Some research in the realm of teaching vocabulary with technology has drawn substantial attention in the academic field. The most cited analysed articles (more than a hundred in-text citations) for the last ten years are devoted to a general overview of the topic: "Twenty years of MALL project implementation: A meta-analysis of learning outcomes" (238) (Burston, 2015), "Research trends in mobile-assisted language learning from 2000 to 2012" (175) (Duman, Orhon \& Gedik, 2015), "Learner interaction in a massively multiplayer online role-playing game (MMORPG): A sociocultural discourse analysis" (169) (Peterson, 2012), "The effects of hypertext glosses on L2 vocabulary acquisition: A meta-analysis" (110) (Yun, 2011). There are some highly sighted articles focusing on interaction in the process of vocabulary learning: "Virtual social network communities: An investigation of language learners' development of sociopragmatic awareness and multiliteracy skills"(160) (Blattner, \& Fiori, 2011), "Games in Language Learning:

(C) Oksana Zabolotna, Liudmyla Zagoruiko, Ielyzaveta Panchenko, Yevhen Plotnikov. 2021. Published by Igor Sikorsky Kyiv Polytechnic Institute. This is an Open Access article distributed under the terms of the licence CC BY 4.0 
Opportunities and Challenges" (145) (Godwin-Jones, 2014), "Effects of captioning on video comprehension and incidental vocabulary learning" (127) (Montero et al., 2014), "Computer-assisted second language vocabulary learning in a paired-associate paradigm: A critical investigation of flashcard software" (124) (Nakata, 2011), "Users' familiar situational contexts facilitate the practice of EFL in elementary schools with mobile devices" (110) (Hwang \& Chen, 2013).

The authors have encountered few literature review articles tracking the developments in this research area and no articles using bibliometric methods or science maps. Moreover, the authors have not encountered a bibliometric analysis of teaching/learning vocabulary online with an expert evaluation of the tools as a follow up.

\section{Methods}

In the study, we used two primary methods: bibliometric analysis and the Delphi method. Firstly, we will describe in what way the bibliometric method was applied.

Bibliometric Database. In the proposed study, we used bibliometric data retrieved from the Scopus and Google Scholar databases. The authors chose the Scopus database as it contains a wide range of peerreviewed journals, provides a recognised index and other bibliographic indices (Mishra et al., 2021; Shen \& Ho, 2020). Google Scholar as an online engine was used as it contains a wide range of citation sources (Roemer \& Borchardt, 2015). Google Scholar was applied to define the most cited articles from the studied pool of journals.

Data selection. All the journals are fully-refereed, and Scopus indexed (see Table 1) and are devoted to research related to technology use in second or foreign language teaching and may fall under the description given in the "Aims and Scope" of the journal webpage, similar to the following: "...the journal seeks to disseminate research to foreign and second language educators on issues related to technology and language education. The focus of $[\ldots]$ is not technology per se, but rather issues related to language learning and language teaching, and how they are affected or enhanced by the use of digital technologies." (Language Learning \& Technology, n.d.)

For the in-depth analysis, we selected eight journals that meet the following criteria: focus on language learning and technologies; are included in the Scopus database; are international with English as the language of publication (see table 1).

Table 1. Journals included in the bibliometric analysis

\begin{tabular}{|c|c|c|c|}
\hline Title & Country & Publisher & Link \\
\hline $\begin{array}{l}\text { Language Learning and } \\
\text { Technology }\end{array}$ & United States & $\begin{array}{l}\text { University of Hawaii } \\
\text { Press }\end{array}$ & https://www.lltjournal.org \\
\hline $\begin{array}{l}\text { Computer-Assisted } \\
\text { Language Learning }\end{array}$ & United Kingdom & Taylor and Francis & $\begin{array}{l}\text { https://www.tandfonline.com/toc/ncal2 } \\
\text { 0/current }\end{array}$ \\
\hline CALICO Journal & United States & Equinox Publishing Ltd & $\begin{array}{l}\text { https://journals.equinoxpub.com/CALI } \\
\text { CO/index }\end{array}$ \\
\hline ReCALL & United Kingdom & $\begin{array}{l}\text { Cambridge University } \\
\text { Press }\end{array}$ & $\begin{array}{l}\text { https://www.cambridge.org/core/journa } \\
\text { ls/recall }\end{array}$ \\
\hline $\begin{array}{l}\text { Teaching English with } \\
\text { Technology }\end{array}$ & Poland & $\begin{array}{l}\text { IATEFL Poland. } \\
\text { Computer Special } \\
\text { Interest Group } \\
\end{array}$ & http://www.tewtjournal.org/ \\
\hline JALT CALL Journal & Japan & JALTCALL SIG & https://journal.jaltcall.org \\
\hline CALL-EJ & Australia & Pascall & http://callej.org \\
\hline $\begin{array}{l}\text { International Journal of } \\
\text { Computer-Assisted } \\
\text { Language Learning and } \\
\text { Teaching }\end{array}$ & United States & IGI Global Publishing & $\begin{array}{l}\text { https://www.igi- } \\
\text { global.com/journal/international- } \\
\text { journal-computer-assisted- } \\
\text { language/41023 }\end{array}$ \\
\hline
\end{tabular}

Although teaching language with technology research may appear in a wide variety of professional media, we based the choice upon the exhausting list of journals exclusively devoted to the area of technology-enhanced language learning. We revealed three subject categories proposed by Scopus, which are close to our research topic - Language and Linguistics, Linguistics and Language and Education. The information on the representation of the selected journals in different categories of Scopus ratings is given in the table (see table 2). 
Table 2. Scopus database bibliometric information on the selected journals

\begin{tabular}{|c|c|c|c|c|c|c|c|}
\hline \multirow{2}{*}{ Title } & \multirow[t]{2}{*}{ SJR } & \multicolumn{2}{|c|}{$\begin{array}{l}\text { Language and } \\
\text { Linguistics }\end{array}$} & \multicolumn{2}{|c|}{$\begin{array}{l}\text { Linguistics } \\
\text { and Language }\end{array}$} & \multicolumn{2}{|c|}{ Education } \\
\hline & & Rank & $\begin{array}{l}\text { SJR } \\
\text { Quart } \\
\text { ile }\end{array}$ & Rank & $\begin{array}{l}\text { SJR } \\
\text { Quart } \\
\text { ile }\end{array}$ & Rank & $\begin{array}{l}\text { SJR } \\
\text { Quart } \\
\text { ile }\end{array}$ \\
\hline Language Learning and Technology & 2,011 & 12 & Q1 & 14 & Q1 & 42 & Q1 \\
\hline Computer-Assisted Language Learning & 1,848 & 17 & Q1 & 18 & Q1 & $\mathrm{n} / \mathrm{a}$ & $\mathrm{n} / \mathrm{a}$ \\
\hline CALICO Journal & 1,827 & 18 & Q1 & 19 & Q1 & 52 & Q1 \\
\hline ReCALL & 1,058 & 47 & Q1 & 56 & Q1 & 156 & Q1 \\
\hline Teaching English with Technology & 0,517 & 129 & Q1 & 146 & Q1 & 450 & Q2 \\
\hline JALT CALL Journal & 0,25 & 238 & Q2 & 265 & Q2 & 812 & Q3 \\
\hline CALL-EJ & 0,24 & 246 & Q2 & 275 & Q2 & $\mathrm{n} / \mathrm{a}$ & $\mathrm{n} / \mathrm{a}$ \\
\hline $\begin{array}{l}\text { International Journal of Computer-Assisted } \\
\text { Language Learning and Teaching }\end{array}$ & 0,249 & $\mathrm{n} / \mathrm{a}$ & $\mathrm{n} / \mathrm{a}$ & 268 & Q2 & \begin{tabular}{|l}
816 \\
\end{tabular} & Q3 \\
\hline
\end{tabular}

\section{Types of Data}

The analysis covers only full-length articles published between 2011 and 2020 . The authors did not take into account book reviews, conference proceedings and other types of publications.

\section{Data collection}

The authors have taken the following steps to collect the data on the studied topic: (1) Scopus database search in the subject categories; (2) Limitations of the journals to the ten-year period; (3) Selection of publications according to its type (journal articles); (4) Shortlisting publications using keywords (titles and abstracts); (5) Selection of publications (205) for bibliometric analyses.

The authors applied Delphi Method after finalising and structuring the bibliometric analysis data. The authors have approached the British Council experts who were involved in the New Generation School Teacher Project $(2013-2020)$, which is an initiative that focused on reforming both the content and the methodology of the traditional approach to preparing future EFL teachers in Ukrainian higher education institutions. In the first round, the experts responded to the questionnaire based on the bibliometric analysis results. The questionnaire contained questions for multiple-choice and prioritising/ranking and open-ended ones that allowed further explanation and argumentation. In the second round, the authors (in this case facilitators) wrote an anonymised summary (with coding the experts R1-R11) of the experts' evaluative ideas and the reasons they provided for their judgments on the virtual interactive board, and provided the link to the experts for peer-commenting, and revise their own opinions in real-time. Finally, the authors summarised the ideas of 11 experts who are EFL Methodology teachers at 6 Ukrainian Universities. The experts have shared their experience in using the tools identified by the bibliometric analysis and listed the usability precedency and hurdles with their recommendations.

\section{Results}

The bibliometric analysis stated that out of 203 articles under study $74(36,5 \%)$ applied quantitative methods, $53(26,1 \%)$ - qualitative methods, $42(20,7 \%)$ - mixed methods, $19(9,4 \%)$ were literature reviews, $11(5,4 \%)$ were case-studies and $4(2 \%)$ articles presented meta-analysis.

The abstract/ keywords analysis helped classify the articles by the technology categories presented as means of teaching/learning vocabulary. These are: Content Development Tools (tools for digital content creation), Learning Platforms and Training Tools (set of interactive online services that provide learners with information, tools and resources to support training), Social Tools (media tools that provide opportunities for synchronous communication), Personal Tools (individualised tools), Search and Reference Tools (help students to find and cite the works), Other Technologies, Approaches and Issues (See figure 1).

The percentage of articles in each group is different - from Search and Reference Tools $(27,4 \%)$ and Learning Platforms and Training Tools $(26,9 \%)$ described in more than a half articles to Content 
Development Tools (13,5 \%), Social Tools (25\%), Personal Tools (13,9 \%), Other Technologies, Approaches and Issues $(6,3 \%)$.

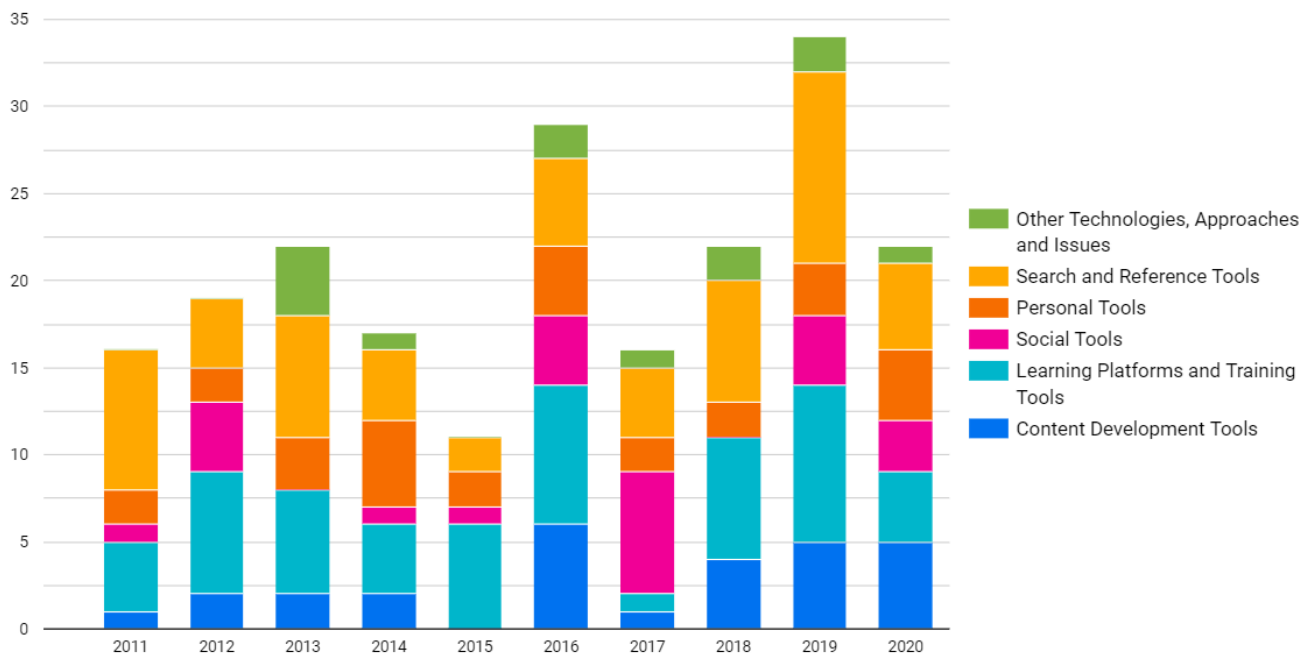

Figure 1. Distribution of the research articles according to the technology categories they focus on

Each category was deeper analysed for specific tools used for technology-aided teaching/learning vocabulary. We are presenting the key groups of tools referred to in each category as through Delphi method the experts have expressed their opinion on them thus contributing to the answer to the research questions "Which tools are frequently addressed in EFL Methodology course in Ukrainian universities for teaching vocabulary online?", "Which tools and methods require more information to be used for teaching vocabulary online?" In the first round, the experts filled in the questionnaire asking them about the categories of tools mentioned in the table (see table 3). They reported a frequent use of some tools in each category, mentioning that they «Show/ explain to students of the ELT Methodology Course how these tools can be used in their English language classrooms with secondary school learners in their future profession. Very often, they begin to use them for their vocabulary learning»(R4). The table below (see table 3) presents the information about the groups of tools based on the Scopus database bibliometric information on the selected journals. It demonstrates the percentage of the analysed articles dealing with a particular tool (\%1), the percentage of experts who state that they frequently use it in their teaching and introduce it in EFL Methodology course $(\% 2)$ and the percentage of experts who would like to try the tool in their teaching but need more information about it (\%3).

Table 3. Groups of tools based on Scopus database bibliometric information on the selected journals

\begin{tabular}{|c|c|c|c|c|c|c|c|}
\hline $\begin{array}{l}\text { Search and Reference } \\
\text { Tools ( } 57 \text { articles) }\end{array}$ & $\% 1$ & $\% 2$ & $\% 3$ & $\begin{array}{l}\text { Content Development Tools ( } 28 \\
\text { articles) }\end{array}$ & $\% 1$ & $\% 2$ & $\% 3$ \\
\hline digital glossaries & 23 & 45 & 18 & digital storytelling apps/ software & 22 & 27 & 55 \\
\hline corpus-based solutions & 21 & 36 & 45 & video & 22 & 91 & 0 \\
\hline e-dictionary & 15 & 100 & 0 & animation & 12 & 36 & 27 \\
\hline video captions & 16 & 34 & 27 & podcasts & 7 & 100 & 0 \\
\hline digital annotations & 7 & 18 & 55 & augmented and virtual reality tools data & 7 & 18 & 55 \\
\hline online search & 7 & 100 & 0 & visualisation & 7 & 82 & 8 \\
\hline online translate & 3 & 82 & 0 & social media (blogs) & 7 & 46 & 18 \\
\hline automated indices & 2 & 0 & 36 & office software & 4 & 55 & 0 \\
\hline online concordancer & 2 & 36 & 55 & listening diary & 4 & 9 & 36 \\
\hline tools with analytical rubrics & 2 & 18 & 46 & simulation app/software & 4 & 0 & 73 \\
\hline text-profiling apps/software & 2 & 36 & 27 & image-to-text recognition & 4 & 9 & 46 \\
\hline Social Tools ( 25 articles) & & & & $\begin{array}{l}\text { Learning Platforms and Training } \\
\text { Tools (56 articles) }\end{array}$ & & & \\
\hline $\begin{array}{l}\text { computer-mediated } \\
\text { communication } \\
\text { videoconferencing tools }\end{array}$ & $\begin{array}{l}4 \\
8\end{array}$ & $\begin{array}{l}46 \\
100\end{array}$ & 64 & $\begin{array}{l}\text { mobile apps (microlearning) } \\
\text { multimedia app/software } \\
\text { online training (exercises) }\end{array}$ & $\begin{array}{l}44 \\
23 \\
13\end{array}$ & $\begin{array}{l}73 \\
55 \\
73\end{array}$ & $\begin{array}{l}27 \\
18 \\
18\end{array}$ \\
\hline
\end{tabular}




\begin{tabular}{|c|c|c|c|c|c|c|c|}
\hline $\begin{array}{l}\text { social networks } \\
\text { synchronous online } \\
\text { communication tools } \\
\text { asynchronous online } \\
\text { communication tools }\end{array}$ & $\begin{array}{l}24 \\
24 \\
40\end{array}$ & $\begin{array}{l}82 \\
82 \\
91\end{array}$ & $\begin{array}{l}9 \\
27 \\
9\end{array}$ & $\begin{array}{l}\text { online course } \\
\text { online testing/assessment } \\
\text { learning management systems }\end{array}$ & $\begin{array}{c}11 \\
5 \\
4\end{array}$ & $\begin{array}{l}45 \\
64 \\
54\end{array}$ & $\begin{array}{l}27 \\
27 \\
36\end{array}$ \\
\hline $\begin{array}{l}\text { Other Technologies, } \\
\text { Approaches and Issues (13 } \\
\text { articles) }\end{array}$ & & & & Personal Tools (29 articles) & & & \\
\hline $\begin{array}{l}\text { general issues in computer- } \\
\text { assisted vocabulary learning } \\
\text { data-driven learning } \\
\text { interactive devices } \\
\text { digital sensor } \\
\text { technology/devices } \\
\text { online reading } \\
\text { interactive reading } \\
\text { eye-tracking }\end{array}$ & $\begin{array}{c}23 \\
23 \\
15 \\
\\
15 \\
8 \\
8 \\
8\end{array}$ & $\begin{array}{l}63 \\
0 \\
73 \\
\\
27 \\
73 \\
18 \\
0\end{array}$ & $\begin{array}{l}30 \\
60 \\
20 \\
50 \\
0 \\
50 \\
90\end{array}$ & $\begin{array}{l}\text { digital/online games } \\
\text { digital flashcards } \\
\text { online portfolio } \\
\text { personal digital assistants }\end{array}$ & $\begin{array}{c}62 \\
32 \\
3 \\
3\end{array}$ & $\begin{array}{c}55 \\
27 \\
45 \\
9\end{array}$ & $\begin{array}{l}36 \\
45 \\
36 \\
73\end{array}$ \\
\hline
\end{tabular}

The data retrieved from the experts demonstrate that the predominantly used tools addressed in the EFL Methodology course in Ukrainian universities are e-dictionaries, online search engines, podcasts, online translate tools, videos, data visualisation tools, videoconferencing tools, social networks, synchronous and asynchronous online communication tools. The ideas coming from the experts are as follows: "As to using digital glossaries, I prefer to engage the students into creating their glossary using some opportunities for simultaneous work. We use video captions for dubbing videos (when the original sound is muted). Also, students make video captions in Ukrainian using Visual Studio software" (R1); "The resources that I like and use for teaching vocabulary online are: https://www.freecollocation.com/ https://dictionary.cambridge.org/ https://www.thesaurus.com/ These three are the most common. In my opinion, an important issue is to make students aware of the possible online resources, to teach them to use them independently for both teaching and learning purposes, to integrate them appropriately in the teaching process" (R11).

As to the content development, the experts advise "such tools as storyboard.com; webquesr.org; puzzlemakers; QR-code generators; Audacity for audio blogs; SurveyMonkey; podOmatic.com" (R3); "Edpuzzle, Padlet, Kialo" (R9). They emphasise the importance of applying a hands-on approach in teaching students to apply the tools in the classroom: "During Methodology sessions or as a follow-up activity, I suggest that my students try their hand at some content development tools, design the segment of a lesson plan with the focus on vocabulary learning using them. I also ask to share the other resources they use and explain why they recommend them" (R4).

The experts advise that the following social tools should be used in teaching vocabulary online (but not restricted to it as they are used for teaching and learning different EFL aspects and gaining skills): Skype, Zoom, Facebook, Facetime, Whatsapp, Viber, Gmail, FLTEACH, Google meet, Moodle, Google Classroom, Big Blue Button, Instagram, Tik-Tok, Telegram bots, and stress the particular rise in their popularity in the recent time challenged by Covid-19. In sharing their experience of using learning platforms and training tools in their teaching, the experts mention Word Wall, Padlet, Kahoot, Google Assistant, Siri. They also emphasise the importance of using online portfolios "which include the designed items. This is the evidence of the students' skills and professional development" (R10)

The most significant percentage of the analysed articles was devoted to the research of how different search and reference tools can be used for teaching vocabulary online. The data received from the experts demonstrate that, in this category, the tools for online concordancer and digital annotations draw a substantial interest as more than half of respondents state that they would like to try them in their teaching. The same is true for the tools dealing with digital storytelling apps/software, augmented and virtual reality tools and simulation app/software in the Content Development Category. Out of the social tools, computermediated communication is in the expert focus as the one that requires more information. The experts would also like to get more information about personal digital assistants and their application and how to use eyetracking tools.

\section{Discussion}

This paper presents mixed-method research on teaching vocabulary online using a combination of quantitative (bibliometric approach) and qualitative (expert evaluation based on Delphi technique) methods 
to get a deeper understanding of how EFL Methodology course in Ukrainian universities prepares students for teaching vocabulary online.

To answer the research question (Which tools in teaching language with technology have been described in research publications?), the authors have used a bibliometric approach to analyse the topicrelated articles in the eight most relevant journals from the Scopus Database between 2011 and 2020. The authors have divided the addressed tools in the analysed publications into the following categories: Content Development Tools, Learning Platforms and Training Tools, Social Tools, Personal Tools, Search and Reference Tools, and Other Technologies, Approaches and Issues. Each category was deeper analysed for specific tools used for technology-aided teaching/learning vocabulary.

From the bibliometric analysis followed by the application of the Delphi method described above, key findings emerge. The experts state that the frequently addressed tools in EFL Methodology course in Ukrainian universities for teaching vocabulary online are e-dictionaries, online search engines, podcasts, online translate tools, videos, and data visualisation videoconferencing tools, social networks, synchronous and asynchronous online communication tools. Simultaneously, the results highlight that little is known about the tools for online concordancer and digital annotations, tools dealing with digital storytelling apps/ software, augmented and virtual reality, simulation apps/software, computer-mediated communication, personal digital assistants and eye-tracking devices.

Contrary to the findings of the expert evaluation that pointed to little attention to these tools, digital storytelling mobile applications and computer software have drawn a lot of researchers' attention (Hwang et al., 2016; Del-Moral-Pérez, Villalustre-Martínez \& Neira-Piñeiro, 2019; Chiew et al., 2019; Liu, Wang \& Tai, 2016; Oskoz \& Elola, 2016). Hwang and others (2016) describe the use of storytelling via a Web-based multimedia system to foster EFL students' speaking skills. The results show the significant influence of the system-supported storytelling on boosting speaking skills. The authors state that applying animation in the EFL classroom contributes to better speaking performance and that individual work on storytelling grants to better learning achievement of EFL students in speaking (Hwang et al., 2016). Other authors focus on the role of digital storytelling in primary classrooms in terms of motivation and engagement (Chiew et al., 2019) and vocabulary and oral fluency (Liu, Wang \& Tai, 2016). According to Del-Moral-Pérez, VillalustreMartínez and Neira-Piñeiro (2019), digital storytelling contributes to primary school students' communicative and digital competencies. Written compositions can support DST's communicative skills, and digital skills are developed by using complex digital tools (audio-visual techniques).

By comparing the results from expert evaluation with the cutting-edge research in the area, firstly, we hope to offer new ways of diversifying classroom practices, and secondly, we encourage more profound research of the peculiarities of their practical application. Those who are interested in introducing tools for creating digital annotations in their teaching may find some theory and practice on how to do it in several recent academic papers (Tseng, Yeh \& Yang, 2015; Mohsen, 2016; Boers, Warren, Grimshaw \& SiyanovaChanturia, 2017; Ajabshir \& Sadeghi, 2019). Tseng, Yeh \& Yang (2015) conducted quantitative research based on an adaptation of Kintsch's Construction-Integration model to define how EFL students gain reading comprehension through online annotations. The research results show the effectiveness of marking vocabulary and adding some explanatory notes in achieving surface comprehension levels in studying vocabulary. Summary notes and text marking contribute significantly to reading comprehension at text-based and situation-based levels. Mohsen (2016) concluded that, in multimedia listening environments, annotated captioned animation and annotated transcript animation almost equally supported students in second language vocabulary acquisition. Boers, Warren, Grimshaw and Siyanova-Chanturia (2017) concluded that, in learning vocabulary, the application of multimodal glosses with digital annotations promotes better word learning than single-mode glosses. Ajabshir and Sadeghi (2019) determine that computer-assisted instruction influences the effectiveness of learning vocabulary by L2 students of high and low proficiency and stressed the significant results of its application while teaching vocabulary to lower-level students. The authors also suggest that teachers and material designers should use digital annotations as an innovative tool for L2 learning. As seen from the overview of the articles mentioned above, the researchers have proven the effectiveness of using digital annotations in the verbal, auditory, and visual modes and have demonstrated various classroom application methods.

The research on the classroom application of augmented and virtual reality tools concerns 3D virtual world and Google Street View. The authors conclude that using a 3D virtual world in a foreign language classroom contributes to acquiring contextualised communicative competence. Students increase their persuasive talk, awareness of audience, and collaborative communication (Yamazaki, 2018); involving Google Street View in a 3D virtual environment at EFL classes helps students acquire target vocabulary, increasing motivation, and deepening language strategy use (Shih, 2020). 
From the articles under bibliometric analysis, EFL practitioners can also get a better understanding of how to use online concordance tools (Daskalovska, 2015), simulation applications/software (Angelini \& García-Carbonell, 2019), tools for computer-mediated communication (Lin, 2015), personal digital assistants (Hwang \& Chen, 2013), and eye-tracking devices (Liu, 2014).

Although based on a broad research overview, the study suffers from some limitations. An apparent limitation of the method is that the experts representing the Universities using the new EFL Methodology curriculum might be unaware of the technology-enhanced tools for teaching vocabulary addressed by the traditional Methodology course. Thus, we can not project the situation to all the Ukrainian universities. However, we acknowledge that there is considerable interest among Ukrainian researchers and EFL practitioners as to the studying how the application of some new vocabulary-focused tools may influence the student's language proficiency. It is important to note that the present evidence relies mainly on the research into blended learning before it was affected by Covid-19. To test how the described tools work in the online classroom, the researchers should deeper consider each of them.

\section{Conclusions}

The research has shown that there are different new and traditional ways of teaching vocabulary online. Some computer-assisted methods are addressed in the University Methodology course that follows New Generation School Teacher Innovative curriculum. The students use them both in their learning and during their school practice; thus there is a high probability that they will use them when they start their teaching career. Nevertheless, there are some tools that the methodologists and students are not familiar with, or they have not practised using them in vocabulary context. A summary of the research on these tools may contribute to boosting the interest in them. However, classroom research on every understudied tool in the Ukrainian educational context may help introduce variety in teaching and learning vocabulary online where the screen is not a barrier.

\section{Acknowledgements}

The authors would like to thank the experts from New Generation School Teacher project Natalia Tuchina and Igor Kamynin (H.S. Skovoroda Kharkiv National Pedagogical University), Inna Samoyliukevych (Zhytomyr Ivan Franko State University), Tetiana Konovalenko and Olha Honcharova (Bogdan Khmelnytsky Melitopol State Pedagogical University), Kateryna Kurysh (Yuriy Fedkovych Chernivtsi National University), Ihor Romanyshyn (Vasyl Stefanyk Precarpathian National University), Alla Gembaruk and Olena Bevz (Pavlo Tychyna Uman State Pedagogical University), Tetiana Larina and Viktoriia Smelianska (Nizhyn Mykola Gogol State University) for sharing their expertise.

\section{References:}

Ajabshir, Z. F., \& Sadeghi, K. (2019). The impact of asynchronous computer-mediated instruction (CAI) on EFL learners' vocabulary uptake across different proficiency levels. Teaching English with Technology, 19(3), 68-89. Retrieved from https://www.tewtjournal.org/?wpdmact=process\&did=NTgxLmhvdGxpbms

Angelini, M. L., \& García-Carbonell, A. (2019). Developing English speaking skills through simulation-based instruction. Teaching $\begin{array}{lllll}\text { English with } & \text { Technology, } & \text { 19(2), } & 3-20 . & \text { Retrieved }\end{array}$ https://www.tewtjournal.org/?wpdmact=process\&did=NTc2LmhvdGxpbms

Blattner, G., \& Fiori, M. (2011). Virtual Social Network Communities: An Investigation of Language Learners' Development of Sociopragmatic Awareness and Multiliteracy Skills. CALICO Journal, 29(1), 24-43. Retrieved April 6, 2021, from http://www.jstor.org/stable/calicojournal.29.1.24

Boers, F., Warren, P., Grimshaw, G., \& Siyanova-Chanturia, A. (2017). On the benefits of multimodal annotations for vocabulary uptake from reading. Computer Assisted Language Learning, 30(7), $709-725$. https://doi.org/10.1080/09588221.2017.1356335

Burston, J. (2015). Twenty years of MALL project implementation: A meta-analysis of learning outcomes. ReCALL, 27(1), 4-20. doi:10.1017/S0958344014000159

Chiew, A., Leong, H., Jafre, M., Abidin, Z., \& Saibon, J. (2019). Learners' perceptions of the impact of using digital storytelling on vocabulary learning. Teaching English with Technology, 19(4), 3-26. Retrieved from https://www.tewtjournal.org/?wpdmact=process\&did=NTk0LmhvdGxpbms

Daskalovska, N. (2015). Corpus-based versus traditional learning of collocations. Computer Assisted Language Learning, 28(2), 130-144. https://doi.org/10.1080/09588221.2013.803982

Del-Moral-Pérez, M. E., Villalustre-Martínez, L., \& Neira-Piñeiro, M. del R. (2019). Teachers' perception about the contribution of collaborative creation of digital storytelling to the communicative and digital competence in primary education schoolchildren. Computer Assisted Language Learning, 32(4), 342-365. https://doi.org/10.1080/09588221.2018.1517094

Duman, G., Orhon, G., \& Gedik, N. (2015). Research trends in mobile-assisted language learning from 2000 to 2012 . ReCALL, 27(2), 197-216. https://doi.org/10.1017/S0958344014000287

Godwin-Jones, R. (2014). Games in language learning: Opportunities and challenges. Language Learning \& Technology, 18(2), 919. http://dx.doi.org/10125/44363 
Hwang, W. Y., \& Chen, H. S. L. (2013). Users' familiar situational contexts facilitate the practice of EFL in elementary schools with mobile devices. Computer Assisted Language Learning, 26(2), 101-125. https://doi.org/10.1080/09588221.2011.639783

Hwang, W. Y., Shadiev, R., Hsu, J. L., Huang, Y. M., Hsu, G. L., \& Lin, Y. C. (2016). Effects of storytelling to facilitate EFL speaking using Web-based multimedia system. Computer Assisted Language Learning, 29(2), $215-241$. https://doi.org/10.1080/09588221.2014.927367

Language Learning \& Technology (n.d.). About us. Aims and scope. Retrieved from https://www.lltjournal.org/about/

Lin, H. (2015). A meta-synthesis of empirical research on the effectiveness of computer-mediated communication (CMC) in SLA. Language Learning \& Technology, 19(192), 85-117. http://dx.doi.org/10125/44419

Liu, C.-C., Wang, P.-C., \& Tai, S.-J. D. (2016). An analysis of student engagement patterns in language learning facilitated by Web 2.0 technologies. ReCALL, 28(2), 104-122. https://doi.org/10.1017/S095834401600001X

Liu, P. L. (2014). Using eye-tracking to understand the responses of learners to vocabulary learning strategy instruction and use. Computer Assisted Language Learning, 27(4), 330-343. https://doi.org/10.1080/09588221.2014.881383

Mishra, M., Sudarsan, D., Santos, C.A.G. et al. ( 2021). An overview of research on natural resources and indigenous communities: a bibliometric analysis based on Scopus database (1979-2020). Environ Monit Assess $193,59$. https://doi.org/10.1007/s10661-020-08793-2

Montero Perez, M., Peters, E., Clarebout, G. \& Desmet, P. (2014). Effects of captioning on video comprehension and incidental vocabulary learning. Language Learning \& Technology, 18(1), 118-141. http://dx.doi.org/10125/44357

Mohsen, M. A. (2016). Effects of help options in a multimedia listening environment on L2 vocabulary acquisition. Computer Assisted Language Learning, 29(7), 1220-1237. https://doi.org/10.1080/09588221.2016.1210645

Nakata, T. (2011). Computer-assisted second language vocabulary learning in a paired-associate paradigm: a critical investigation of flashcard software. Computer Assisted Language Learning, 24, 17 - 38. https://doi.org/10.1080/09588221.2010.520675

Oskoz, A., \& Elola, I. (2016). Digital stories in L2 education: Overview. CALICO Journal, 33(2), 157-173. https://doi.org/10.1558/cj.v33i2.29295

Peterson, M. (2012). Learner interaction in a massively multiplayer online role-playing game (MMORPG): A sociocultural discourse analysis. ReCALL, 24(3), 361-380. https://doi.org/10.1017/S0958344012000195

Roemer, R., \& Borchardt, R. (Eds.) (2015). Meaningful metrics : A 21st century librarian's guide to bibliometrics, altmetrics, and research impact. Chicago: ICRL.

Shen, C. W., \& Ho, J. T. (2020). Technology-enhanced learning in higher education: A bibliometric analysis with latent semantic approach. Computers in Human Behavior, 104, 106177. https://doi.org/10.1016/j.chb.2019.106177

Shih, Y. C. (2020). Vocabulary acquisition from a virtual street-view context. International Journal of Computer-Assisted Language Learning and Teaching, 10, 14-32. https://doi.org/10.4018/IJCALLT.2020100102

Tseng, S. S., Yeh, H. C., \& Yang, S. hsien. (2015). Promoting different reading comprehension levels through online annotations. Computer Assisted Language Learning, 28(1), 41-57. https://doi.org/10.1080/09588221.2014.927366

Yamazaki, K. (2018). Computer-assisted learning of communication (CALC): A case study of Japanese learning in a 3D virtual world. ReCALL, 30(2), 214-231. https://doi.org/10.1017/S0958344017000350

Yun, J.H. (2011). The effects of hypertext glosses on L2 vocabulary acquisition: a meta-analysis. Computer Assisted Language Learning, 24, 39 - 58. https://doi.org/10.1080/09588221.2010.523285

Received: March 10, 2021

Accepted: April 16, 2021 